\title{
RESTITUTION, COERCION BY A THIRD PARTY, AND THE PROPER ROLE OF NOTICE
}

\author{
EOIN O’DELL* \\ I. INTRODUCTION
}

IF a plaintiff makes a payment to a defendant under the coercion of a third party, it has been said ${ }^{1}$ that the plaintiff's action in restitution to recover the payment from the defendant is dependent upon whether the defendant had notice of the third party's coercion. That is an error, to which the analysis here is intended as a corrective. The true view is that the plaintiff's action in restitution is dependent only upon the fact of the coercion vitiating his consent; notice is relevant only to separate the question whether the defendant can rely on the defence of bona fide purchase for value without notice.

\section{The ERror Stated AND Refuted}

\section{The source of the error}

The error is said to follow from the decision of the House of Lords in Barclays Bank v. O'Brien ${ }^{2}$ - to the effect that where a bank has notice of undue influence exercised by a borrower on a surety, then the bank cannot enforce as against the surety - a decision which has been the occasion for much discussion in this Journal, ${ }^{3}$ and elsewhere. ${ }^{4}$ The earlier decision of the House in Lipkin Gorman v. Karpnale proceeded $^{5}$ on the basis that the principle against unjust enrichment is recognised

- Lecturer in Law, Trinity College, Dublin. For their comments on earlier drafts of this article, I would like to thank Sinéad Agnew, Prof. Peter Birks, John Mee, Dr. Lionel Smith, W.J. Swadling, and, especially, Eunice O'Raw.

For example, see the extract set out in the text to fn. 8 and the references in fn. 19 below.

2 [1994] 1 A.C. 180; see also C.I.B.C. v. Pitt [1994] 1 A.C. 200

${ }^{3}$ M. Dixon, "The Special Tenderness of Equity: Undue Influence and the Family Home" [1994] C.L.J. 21; A. Lawson, "O'Brien and its Legacy: Principle, Equity and Certainty ?" [1995] C.L.J. 280; J. Mee, "Undue Influence, Misrepresentation and the Doctrine of Notice" [1995] C.L.J. 536. ${ }^{4}$ E.g. G. Battersby [1995] L.S. 35; A. Berg [1994] L.M.C.L.Q. 34; 5. Cretney [1994] R.L.R. 3; M. Dixon and C. Harpum [1994] Conv. 421; B. Fehlberg (1994) 47 M.L.R. 467; Say Hak Goo (1995) 15 O.J.L.S. 119; R. Hooley [1995] L.M.C.L.Q. 346; J.R.F. Lehane (1994) 110 L.Q.R. 167; J. Mee (1995) 46 N.I.L.Q. 147; P. O'Hagan (1994) 144 N.L.J. 765; P. O’Hagan (1996) 47 N.I.L.Q. 74; P. Sparkes [1995] Conv. 250; M.P. Thompson [1994] Conv. 140. On subsequent applications of O'Brien in the Court of Appeal, see A. Dunn [1995] Conv. 319; B. Fehlberg (1996) 59 M.L.R. 675; H.W. Wilkinson (1995) 145 N.L.J. 792.

${ }^{5}[1991] 2$ A.C. 548. 
by the Common Law; ${ }^{6}$ it also accepted that a defendant in a restitution action could in principle rely on the defence of bona fide purchase. Our understanding of that defence has recently been significantly improved by an important article by Kit Barker. ${ }^{7}$ Drawing on Barker's analysis, and dealing with the interaction between the $O^{\prime}$ Brien principle and the defence, Prof. Birks has this to say:

. . in a case in which the defendant has received from a plaintiff who was then acting under undue influence arising from a relationship with a third party, it is not necessary to say any more than that, by way of pragmatic restriction upon the range of relief that defendant can be liable only for unconscientious receipt. That is to say, only when he has notice of the vitiating factor. [Here, he refers to O'Brien in a footnote.] There is no need to draw an analogy between the defendant who has no such notice and a bona fide purchaser. The only transaction in question is one in which the plaintiff conferred a benefit directly on the defendant. $^{8}$

This analysis is (uncharacteristically) flawed, in that it embodies the error identified at the outset; refuting it entails a return to first principles.

\section{First principles: refuting the error}

Take mistake as a cause of action in restitution. If A induces in B's mind a mistaken belief as a consequence of which $\mathrm{B}$ pays $\mathrm{A}, \mathrm{B}$ can get restitution of that payment from $\mathrm{A}$. Likewise, if $\mathrm{A}$ induces in B's mind a mistaken belief as a consequence of which $\mathrm{B}$ pays not $\mathrm{A}$ but a third party $C$, the authorities are unanimously of the view that $B$ can get restitution of that payment from $\mathrm{C}$. This must be right. Generically, a defendant's enrichment at the expense of a plaintiff will be unjust where the plaintiff's consent to the transaction was impaired, and just such an impairment occurs where the plaintiff is mistaken. The focus of the enquiry is upon the vitiation of consent by mistake, and a plaintiff is mistaken just as much when the defendant induces his mistake as he is when a third party induces the mistake. Thus, when the authorities say that it is not necessary that a mistake be "as between" plaintiff and defendant, they are doing no more than

\footnotetext{
${ }^{6}$ Cp. E. O'Dell, "The Principle Against Unjust Enrichment" (1993) 15 D.U.L.J. (n.s.) 27; cf. S. Hedley " "Unjust Enrichment"” [1995] C.L.J. 578.

K. Barker, "After Change of Position: Good Faith Exchange in the Modern Law of Restitution" in P. Birks (ed.), Laundering and Tracing (Oxford, 1995) p. 191 (hereafter: Barker). See also D. Fox, "Bona Fide Purchase and the Currency of Money" [1996] C.L.J. 547; P. Key, "Bona Fide Purchase as a Defence in the Law of Restitution" [1994] L.M.C.L.Q. 421; and W. Swadling, "Property, Restitution and the Defence of Bona Fide Purchase" in W. Swadling (ed.), The Limits of Restitutionary Claims: A Comparative Analysis (British Institute of International and Comparative Law, forthcoming).

8 P. Birks, "Overview: Tracing, Claiming and Defences" in P. Birks (ed.), Laundering and Tracing (Oxford, 1995), p. 289 (hereafter: Birks "Overview") at p. 334
} 
affirming that what is important is that the plaintiff was mistaken whether or not the defendant contributed to the mistake. ${ }^{9}$

The same point can be made with reference to any factor which impairs a plaintiff's consent. In principle, it is enough that the plaintiff's consent be impaired, it is not necessary that the defendant have impaired it. Thus, where A coerces B to pay C, B's consent is vitiated and he has a cause of action in restitution against $\mathrm{C}$. Such coercion is constituted by duress and actual undue influence, and consent is similarly impaired in the context of presumed undue influence. ${ }^{10}$ Thus, where B transfers to C upon A's direction, in circumstances in which equity will find or presume that $\mathrm{B}$ acted as a consequence of A's undue influence, that impairment of B's consent to the transfer to $\mathrm{C}$ is the basis of B's cause of action in restitution against $\mathrm{C}$. As with mistake above, so with coercion here. ${ }^{11}$

Where A impairs B's consent and B thereby pays C, B's cause of action in restitution against $C$ is subject to the standard limitations on all causes of action in restitution. One such limitation is that if the plaintiff has paid the defendant pursuant to the terms of a valid contract, then the plaintiff's action is barred..$^{12}$ In the simple cases of mistake and coercion already discussed, there is no contract between $\mathrm{B}$ and $\mathrm{C}$, and thus this bar is irrelevant. But in cases like O'Brien, ${ }^{13} \mathrm{~B}$ pays $C$ pursuant to a contract. If that contract is valid, then although $B$ may prima facie have a cause of action against $C$ by virtue of A's coercion, the fact that B pays pursuant to the valid contract is a bar to that claim. Where $\mathrm{C}$ has notice of A's coercion ${ }^{14}$ of $\mathrm{B}$, then the

9 E.g. Jones v. Waring \& Gillow [1926] A.C. 670, 680 per Lord Cave; Porter v. Latec Finance (1964) 111 C.L.R. 177, 204 per Windeyer J.; National Bank v. O'Connor \& Bowmaker (1969) 103 I.L.T.R. 73, 93 per Budd J.; Barclays Bank v. Simms [1980] Q.B. 677, 695 per Goff J.; Australia and New Zealand Banking v. Westpac Banking (1987-1988) 164 C.L.R. 662, 671 per curiam.

10 P. Birks and N.Y. Chin, "On the Nature of Undue Influence" in J. Beatson and D. Friedmann (eds.), Good Faith and Fault in English Law (Oxford, 1995) p. 57; cf. R. Bigwood, "Undue Influence: 'Impaired Consent' or 'Wicked Exploitation'?" (1995) 16 O.J.L.S. 403 (arguing that undue influence is concerned with supplying a remedy for exploitation).

11 See, e.g., A. Burrows, The Law of Restitution (London, 1993) (hereafter, Burrows) p. 161. Cp. J. Mee "An Alternative Approach to Third Party Undue Influence and Misrepresentation" (1995) 46 N.I.L.Q. 147, 149, 155-156 (arguing that such coercion should of itself be enough to vitiate contract)

12 R. Goff and G. Jones, The Law of Restitution (4th ed., London, 1993) (hereafter, Goff and Jones) p. 45; Pan Ocean Shipping v. Creditcorp (The Trident Beauty) [1994] 1 W.L.R. 161, 164f, 165d-e, $166 \mathrm{e}-\mathrm{f}$ per Lord Goff; Pigs and Bacon Commission v. McCarren (1978) Journal of the Irish Society of European Law 77; E. O'Dell [1995] R.L.R. 187, 189.

${ }^{3}$ In $O^{\prime} B r i e n$ and its progeny, no question of restitution seems so far actually to have arisen, as the cases usually involve a bank $C$ seeking to enforce a security against $B$. Birks' proposition assumes that $\mathrm{B}$ has somehow paid $\mathrm{C}$ and is seeking (personal) restitution of that amount. This is most likely to arise in practice where B is a guarantor rather than a surety. This payment scenario is

the only one which could implicate a remedy in restitution, and is the basis of the discussion here.

The text concentrates on the undue influence by $\mathrm{A}$ on $\mathrm{B}$ giving rise to a restitutionary cause of action on the basis of coercion. However, in O'Brien equitable fraud in both undue influence and misrepresentation (e.g. [1994] 1 A.C. 180, 196); for E.R. 951. As to a misrepresentation [1995] 1 All E.R. 929; T.S. B. Bank v. Camfield [1995] 1 All E.R. 951. As to a misrepresentation by A to B, which induces in B's mind a mistake as a consequence of which $\mathrm{B}$ pays $\mathrm{C}$, if such a mistake gives rise to a cause of action in restitution (see 
contract between $\mathrm{B}$ and $\mathrm{C}$ is invalid. ${ }^{15}$ Consequently, $\mathrm{C}$ cannot rely on the bar of payment pursuant to a valid contract, and B once again has a claim in restitution against C. Crucially, then, notice does not constitute B's cause of action, it simply has the effect of displacing C's contract-bar defence. ${ }^{16}$

Another of the standard limitations on all causes of action in restitution is the defence of bona fide purchase: if the defendant has given value to a third party in exchange for the value which the plaintiff now seeks to recover, then, in certain circumstances, he will be able to rely on the defence of bona fide purchase. Eo nomine, it is dependent (at least) upon the notions of "bona fide" and "purchase". In Lipkin Gorman v. Karpnale, ${ }^{17}$ the firm, B, sued the club, C, and C sought to set up as a defence the proposition that it gave value to the gaming solicitor, D. It was held that the nullity of the gaming contract between $\mathrm{C}$ and $\mathrm{D}$ necessarily meant that $\mathrm{C}$ could not rely on the defence of bona fide purchase, since $\mathrm{C}$ were not purchasers for value. But, if as between $\mathrm{C}$ and $\mathrm{D}$ there is a valid contract, then it seems that $\mathrm{C}$ can rely on the defence. There is nothing in the mere fact that B's cause of action arises because A coerced him (or otherwise impaired his consent) to disturb the proposition that C's payment to D may provide $\mathrm{C}$ with a defence against $\mathrm{B}$.

In the payment scenario, $B$ has paid the bank $C$ and now claims restitution, and $\mathrm{C}$ seeks to set up as a defence the proposition that it had given value to the borrower $\mathrm{D}$. If the contract between $\mathrm{C}$ and $\mathrm{D}$ is a valid one, then in principle it would seem that $\mathrm{C}$ can rely on the defence; and this holds even where B's claim against $C$ arises because $B$ had been coerced by A. However, if the coercer A is also the borrower $\mathrm{D}$, the enquiry then becomes whether the defence is still available to $C$, where $A$ has coerced $B$ to pay $C$, and $C$ seeks to deny a restitutionary liability on the grounds that it has paid A/D in return for its receipt from B. And here, the focus is not on the purchase for value, as it was in Lipkin Gorman, but on C's bona fides. If C has

Carey v. Ryan [1982] I.R. 179 (S.C.)), then the authorities (above, fn. 9) establish that B can still analysis in the text applies mutatis mutandis. is Barclas in the text applies mutatis mutandis.

Barclays Bank v. O'Brien [1994] 1 A.C. 180. Since the analysis developed here from the perspective
of the law of Restitution would apply whatever test is applied in the low question of when a contract goes off for whatever test is applied in the law of Contract to the debate as to whether the test ought to be somethine, no position need be taken here on the the notes cited in the something other than notice. On that debate, see Party Undued in fnn. 3 and 4 (above), especially J. Mee, "An Alternative Approach to see Party Undue Influence and Misrepresentation" (1995) 46 No Alternative Approach to Third "Contract" in R. Byrne and W. Binchy (eds. (1995) 46 N.I.L.Q. 147; see also E. O'Dell, Sweet \& Maxwell, Dublin, 1996) p. 176 at pp. 194-209; R V'ow of Irish Law 1993 (Round Hall W. Binchy (eds.) Annual Review) of. forthcoming).

16 If the

If the test for the validity of the contract (above, fn. 15) were predicated on something other than
notice, then notice would not even have this 17 [1991] 2 A.C. 548. 
notice of $A / D$ 's coercion of $B$, then in paying $A / D, C$ might validly have purchased for value, but his notice means that he is not acting bona fide. ${ }^{18}$ Consequently, he cannot take advantage of the defence. Again, notice does not constitute B's cause of action, it simply has the effect of displacing C's bona fide purchase defence.

To sum up so far: if $A$ coerces $B$ to undertake to pay $C$ in certain circumstances, and $\mathrm{C}$ as a consequence pays $\mathrm{A}$, then $\mathrm{C}$ can recover from $B$ on foot of the undertaking only if he does not have notice of $A$ 's coercion; if $C$ has notice, then he cannot recover from $B$ (this is Barclays Bank v. O'Brien). If, on this scenario, B has in fact paid C and now seeks restitution, then since $A$ has coerced $B$ to pay $C, B$ has a prima facie cause of action against $C$ in restitution by virtue of that impairment of B's consent. As to C's defences to this claim: (i) $\mathrm{C}$ can defend on the ground that $B$ paid $C$ pursuant to a valid contract only if $\mathrm{C}$ did not have notice of A's coercion (as such notice, according to $O$ 'Brien, renders the contract between $\mathrm{B}$ and $\mathrm{C}$ invalid); and (ii) $\mathrm{C}$ can defend on the ground that by virtue of C's payment to $A, C$ was a bona fide purchaser for value only if $\mathrm{C}$ did not have notice of A's coercion. In all of these permutations, therefore, C's notice of A's coercion of B prevents C enforcing his contract with B, and is sufficient answer both to the defence that $\mathrm{B}$ paid $\mathrm{C}$ under a valid contract and to the defence that $\mathrm{C}$ is a bona fide purchaser. However, in none is notice an ingredient of the cause of action in restitution.

\section{Refuting Birks' and Barker's formulations of the error}

Now consider Birks' view in the quotation at the start of this comment: $\mathrm{C}$ "can be liable only for unconscientious receipt. That is to say, only when he has notice of the vitiating factor" ${ }^{19}$ This seems to predicate liability in restitution upon notice. Barker explicitly makes the same point: "the notice of the mortgagee [C] in three-party cases like Barclays Bank v. O'Brien is perceived by the courts to be relevant to the plaintiff's [B's] capacity to make out a restitutionary cause of action". ${ }^{20}$ To the extent that their claim is that where B pays $\mathrm{C}$, then $\mathrm{C}$ is liable to B in restitution in every case only if he had notice of A's coercion, this claim simply is not right. It should by now be clear that notice is not an ingredient of the restitutionary cause of action-it simply goes to the denial of certain defences. ${ }^{21}$ Nothing in Barclays

${ }_{18}$ Cp. Nelson v. Larholt [1948] 1 K. B. 339 (Denning J.): C paid D on foot of a cheque drawn on B; (had notice and) was not bona fide; hence ${ }^{2}$ 's failure to make reasonable enquiries meant that he Carey v. Ryan [1982] I.R. 179, 185; Millican v. Robion against C in restitution succeeded. See also 19 Birks "Overview", p. 334; Swadling [1995] All E.R. Rev. 438, 448-451 (semble making (above, fn. 10), at pp. 80-81; $c$. 20 Barker, p. 208. Cf. P. Sparkes [1995] Conv 250,251 .

21 Indeed, in another context, Profesor

of a cause of action in restitution on the grounds thuously argued against notice as an ingredient bona fide purchase. . e. P. Birks, Restitution-The Future (Sydney, 1992) (hereafter, Birks, Future) 
Bank v. O'Brien says otherwise: that case is directed to the separate question of the validity of the contract ${ }^{22}$ between $\mathrm{B}$ and $\mathrm{C}$, and it holds that if $\mathrm{C}$ has notice of $\mathrm{A}$ 's coercion of $\mathrm{B}$, then the contract between $\mathrm{B}$ and $C$ is invalid. The general case remains: if $A$ coerces $B$ and $B$ pays $\mathrm{C}$ otherwise than pursuant to a contract, then prima facie $\mathrm{B}$ can recover from $\mathrm{C}$ simply because of the vitiation of his consent by $\mathrm{A}$ 's coercion, whether or not $\mathrm{C}$ had notice of $\mathrm{A}$ 's coercion.

Furthermore, Birks' reference to "unconscientious receipt" ${ }^{\text {"23 }}$ is also unfortunate. It suggests a defendant-sided ground for restitution, whereas it is clear that the ground for restitution in such circumstances is avowedly plaintiff-sided: the impairment, by coercion, of B's consent. Again, Birks' claim that "[t]here is no need to draw an analogy between the defendant who has no such notice [of a vitiating factor] and a bona fide purchaser" 24 is likewise unhappy, since, if, as the treatment here has demonstrated, the presence of notice renders a purchase otherwise than bona fide, then it follows that it is precisely the absence of such notice which renders the purchase bona fide.

\section{A Second ERror Stated and Refuted}

\section{The source of the second error}

It will now be clear that, in the law of Restitution, the proper role of notice is not in any of its causes of action, but in the defence of bona fide purchase for value without notice. However, by thus excising notice from the cause of action and locating it in this defence, the treatment so far has argued for the availability of such a defence in principle in the payment scenario. Nevertheless, because Birks and Barker, in error, see notice as relevant to the cause of action where a third party coerces the plaintiff, they are led into the further error of denying that the defence of bona fide purchase would be available to the defendant in such circumstances; refuting this error entails an analysis of the basic principles underlying the defence.

chapter 2; (1989) 105 L.Q.R. 352; (1989) 105 L.Q.R. 528; [1989] L.M.C.L.Q. 296; [1991] L.M.C.L.Q. 473; [1993] L.M.C.L.Q. 218; (1993) 46(1) C.L.P. 157. Following Birks on this point, Barker also rejects notice in that context: Barker, pp. 193, 209.

22 The question of the validity of a contract according to the law of Contract, and the (consequent) availability of a remedy according to the law of Restitution if the contract is invalid, are in principle two separate enquiries. (See e.g. D. Friedmann, "Valid, Voidable, Qualified, and Nonexisting Obligations: An Alternative Perspective on the Law of Restitution" in A. Burrows (ed.), Essays on the Law of Restitution (Oxford, 1991) p. 247, at pp. 260-263, 277). The requirement of notice in O'Brien is directed (only) to the first of those enquiries; the analysis presented here is directed (only) to the second. Of course, strictly speaking, the remedy for undue influence is rescission on terms; on this view, the material in the text should be seen as defining the circumstances when such terms should amount to restitution.

23 Birks "Overview", p. 334

24 Ibid. 


\section{Refuting the second error}

The availability of the defence to such a defendant is entirely consistent with the rationale(s) articulated by Barker for the defence: that it is necessary for "promoting commercial certainty", 25 as "the need for security in commercial exchange-transactions is currently perceived (rightly or wrongly) to be so important that it will prevail even where the receipt of money under such a transaction has precipitated no unfairness upon the recipient" ${ }^{26}$ The same certainty is achieved equally by saying either that the defence is not available (Barker, Birks), or that it is available but it fails ${ }^{27}$ (as here): in both cases the plaintiff wins. The case in which they would deny, but the treatment here would allow, the defence-where the bank seeks to retain a payment from a surety where it had no notice of the borrower's coercion of the suretyis one in which the need for "security in commercial exchangetransactions" clearly pulls in favour of the security of the bank's receipt. ${ }^{28}$

Barker counters that, in this example, the fact that there is a contract between the surety and the bank, that is between B and C, is itself a bar to B's action in restitution, and is enough to displace the need to rely on the defence. ${ }^{29} \mathrm{But}$, and this is crucial, the fact that one defence succeeds on certain facts should not displace the principle that another might also be available in theory. Indeed, it is not fanciful to suggest that the contract between $B$ and C could go off for all manner of reasons unrelated to coercion or A's bona fides, such as B's incapacity, or failure to comply with situation-specific statutory requirements, ${ }^{30}$ or because $\mathrm{B}$ had made a sufficiently fundamental mistake. ${ }^{31} \mathrm{~B}$ nevertheless pays $\mathrm{C}$, and thereafter seeks restitution. If $\mathrm{B}$ then shows that $C$ was unjustly enriched at his expense, why should $C$ not be able to set up the defence of bona fide purchase? Certainly, the contract bar does not do the work, and if commercial certainty requires the security of C's receipt, then the defence of bona fide purchase must be admitted.

Of course, in the payment scenario, if B's contract with $\mathrm{C}$ is set

25 Barker, p. 198.

26 Ibid. Similarly, Burrows (at p. 472) says that "at root, the idea [behind the defence] appears to be one of maintaining the sanctity of contracts. The courts are generally not prepared to disturb a contract unless the purchaser for value was contracting in bad faith...".

27 The defendant's notice of the third party's coercion means that the defendant is not bona fide: text with fn. 18 above.

${ }^{28} C_{p}$. Mee (above, fn. 14), at pp. 156-157, 160-161.

29 Barker, pp. 204-205; cp. pp. 200-201.

${ }^{30}$ For example, B could be bankrupt, and have given the security as a fraudulent preference. Again, there could be a statutory provision, similar to s. 3 of Ireland's Family Home Protection Act, 1976 which limits a spouse's dealing with family property, and may render the guarantee void.

31 If the test for the validity of a contract procured by the undue influence of a third party is based on something other than notice (see above, fn. 15 ), then undue influence itself could also be added to this list. 
aside on the basis of C's notice of A's coercion of B, then in B's action in restitution to recover back any payments made to $C, C$ 's notice of A's coercion of $\mathrm{B}$ means that $\mathrm{C}$ cannot rely on the defence of bona fide purchase. Since this will be the most common pattern, B will not usually be met successfully with the defence, but this provides no reason in principle to preclude $\mathrm{C}$ from seeking in an appropriate case
to rely upon it.

\section{Refuting Birks' and Barker's formulations of the second error}

For Barker, the defence is paradigmatically allowed where the defendant receives the benefit by virtue of a contract with the third party 32 and it is paradigmatically disallowed where the defendant receives the benefit directly from the plaintiff by virtue of a contract with the plaintiff. An intermediate position, containing elements of both paradigms, in which the defendant receives the benefit by virtue of a contract with a third party, but receives it directly from the plaintiff, Barker locates in the first paradigm thereby allowing the defence. ${ }^{33}$ Nothing said here is intended to displace any of these conclusions.

However, the payment scenario (where $\mathrm{B}$ has paid the bank $\mathrm{C}$ and now claims restitution, and $\mathrm{C}$ seeks to set up as a defence the proposition that it had given value to the borrower D) is another intermediate position, containing elements of both paradigms: it has been demonstrated above that the policy underlying the defence applies here so that, in principle, it ought to be available. However, Birks and Barker would deny ${ }^{34}$ this conclusion. Thus, in the last sentence of the statement which inspired the present comment, Birks points out that "[t]he only transaction in question is one in which the plaintiff conferred a benefit directly on the defendant", 35 and soon explains that this is "not a fact situation to which the defence of bona fide

32 Thus, where $A$ obtains money from $B$, in circumstances giving $B$ a claim against $A$, and $A$ then pays it to a bank $C$, it may be that $B$ could also have a claim in $B$ a claim against $A$, and $A$ then no notice of those circumstances (above, fn. 18) ane a claim in restitution against $C$, unless $C$ has loan or overdraft (Barker, pp. 202-203). it gave value to A (its repaying debtor); in the B sues C, who seeks to defend on the ground that that it gave value to $\mathrm{A}$ (the borrower debtor). From $\mathrm{C}$ 's $\mathrm{C}$, who seeks to defend on the ground exactly the same; the defence is uncontrover). From C's perspective, its position in both cases is of the argument in the text is that (pace Barker) it is ailable in the first case, and the consequence ${ }^{33}$ Barker, p. 204.

(he second.

As a personal restitutionary claim, it would also be denied by those who confine pure proprietary claims, e.g. Key (above, fn. 7) The Law of Restitution (O. Taddaugh and J.D. McCamus, view ([1989] L.M. C. view (Future, pp. 132-135; "Overview", p. 333) which 473, 490) but now supports the contrary support: e.g. Barker, pp. 194-195, 213-214; Burrows currently seems to command majority Toronto, 1992), pp. 451-453; Goff and Jones, pp. 760-762. K. G. Fridman, Restitution (2nd ed., Law in Australia (Sydney, 1995), p. 865 stop , pp. 760-762. K. Mason and J.W. Carter, Restitution for a ... bona fide purchaser defence to personal claims"

${ }^{35}$ Birks "Overview", p. 334. 
purchase applies". ${ }^{36}$ Similarly, for Barker, the defence "only applies (is only needed) ... [otherwise than where the defendant] receives it under a (voidable) contract with the plaintiff himself" ${ }^{37}$ However, the payment scenario is an example of circumstances where (for reasons of commercial certainty) the defence is in fact needed even though the defendant receives under a contract with the plaintiff himself; in such a case, the defence should prima facie be available to $\mathrm{C},{ }^{38}$ though it will fail where $C$ has notice of $A$ 's coercion.

\section{CONCLUSION}

The theme developed here has been that where A coerces B to pay C, $B$ 's cause of action in restitution against $C$ is based simply on the impairment (by A) of B's consent; it is not right as a matter of principle to say, as Birks and Barker do, that B's action is dependent upon whether C had notice of A's coercion of B. However, to meet both the fear of too much restitution ${ }^{39}$ and the need for security in commercial exchange-transactions, where $\mathrm{C}$ has in fact paid $\mathrm{A}$, the defence of bona fide purchase for value without notice ought in principle to be available to C. Birks and Barker, by locating the enquiry as to notice in the cause of action, deny the relevance of the defence in such a situation. The treatment here, by demonstrating that locating notice in the cause of action in restitution is an error, argues that such a defence ought to be available. In conclusion, therefore, in an action for restitution on the basis of coercion by a third party, the cause of action arises simply from the vitiation of the defendant's consent, and the proper role of notice is as an element of the defence of bona fide purchase for value without notice.

${ }_{37}^{36}$ Ibid. p. 335.

${ }_{38}^{37}$ Barker, p. 199, emphasis added.

38 A point with which Birks would not have disagreed when he characterised the defence thus: "the defendant says that, although he received it, yet because of this value received, and in exch. "the for it, he conferred a valuable benefit on the person (ne of this value received, and in exchang received it, so that his enrichment cannot be assosed (not being now the plaintiff) from whom he cf. P. Birks, Introduction to the Law of Restitution (Oxford, 1985, revised 1989), pp. 439-447. Clearly, on our facts, $\mathrm{C}$ [who, because of the value received, and in exchange for it, conferred a valuable benefit on A (and not on the plaintiff B)] would have fulfilled that definition of the
defence and had the benefit of it.

39 P. Birks and N.Y. Chin (above, fn. 10), at p. 80. 